\title{
PENGARUH UMUR PANEN YANG BERBEDA TERHADAP PRODUKSI DAN KANDUNGAN BAHAN KERING SERTA PROTEIN KASAR SORGHUM GREEN FODDER HYDROPONIC
}

\author{
(Effect of Different Harvesting Age on Production and Content of Dry Matter and Crude \\ Protein Sorghum Green Fodder Hydroponic
}

\author{
Sri Widiastuti ${ }^{1}$, Tri Puji Rahayu ${ }^{1}$, dan Mohamad Haris Septian ${ }^{1}$ \\ ${ }^{1}$ Universitas Tidar, Jl. Kapten Suparman No.39, Tuguran, Potrobangsan, Kec. Magelang Utara, \\ Kota Magelang, 56116 \\ Email korespondensi: sw191999@gmail.com
}

\begin{abstract}
Hydroponics is a forage cultivation technique that is suitable to be applied to overcome the constraints of climate dependence and land availability. Forage that is cultivated hydroponically is often called green fodder hydroponic. Sorghum is a plant that has the potential to be developed as a hydroponic green fodder because it grows well in tropical environments and is efficient in producing photosynthetic products. This study aims to determine the content and production of Dry Matter (DM) and Crude Protein (CP) sorghum green fodder hydroponic. The study was conducted experimentally with a completely randomized design. The collected data were analyzed using Duncan's Test. The treatments were harvesting ages of 7 days, 10 days and 13 days, then measured the production of fresh ingredients, $\mathrm{DM}$ content, $\mathrm{DM}$ production, $\mathrm{CP}$ content, and $\mathrm{CP}$ production. The results showed that the longer the age of harvest significantly $(p>0.05)$ increased the content of DM and CP but significantly $(\mathrm{p}>0.05)$ decreased the production of fresh ingredients and the production of $\mathrm{DM}$ The results of $\mathrm{CP}$ production showed that the longer the age of harvest was not significant $(\mathrm{p}<0.05)$. In conclusion, the long harvesting age of hydroponic sorghum green fodder causes an increase in the content of $\mathrm{DM}$ and $\mathrm{CP}$, but decreases the production of fresh ingredients and the production of DM
\end{abstract}

Key word : Dry matter, Crude protein, Sorghum green fodder hydroponic, and Age of harvest

\begin{abstract}
ABSTRAK
Hidroponik merupakan teknik budidaya hijauan pakan yang cocok diaplikasikan untuk mengatasi kendala ketergantungan iklim dan ketersediaan lahan. Hijauan pakan yang dibudidayakan secara hidroponik sering disebut dengan green fodder hydroponic.Sorgum merupakan tanaman yang potensial dikembangkan sebagai green fodder hydroponic karena berkembang baik di lingkungan tropis dan efisien dalam menghasilkan produk fotosintesis. Penelitian bertujuan untuk mengetahui kandungan dan produksi BK dan PK sorghum green fodder hydroponic. Penelitian dilakukan secara eksperimental dengan rancangan acak lengkap. Data yang terkumpul dianalisis menggunakan Uji Duncan. Perlakuan yang dilakukan yaitu umur panen 7 hari, 10 hari dan 13 hari, kemudian diukur produksi bahan segar, kandungan BK, produksi BK, kandungan PK, dan produksi PK. Hasil menunjukkan bahwa semakin lama umur panen nyata $(\mathrm{p}<0,05)$ meningkatkan kandungan $\mathrm{BK}$ dan $\mathrm{PK}$, namun nyata $(\mathrm{p}<0,05)$ menurunkan produksi bahan segar dan produksi BK. Pada hasil produksi PK menunjukkan semakin lama umur panen tidak nyata $(\mathrm{p}>0,05)$. Kesimpulan, lama umur panen sorghum green fodder hydroponic menyebabkan peningkatan kandungan BK dan PK, namun menurunkan produksi bahan segar dan produksi BK.
\end{abstract}

Kata Kunci : Bahan kering, protein kasar, sorghum green fodder hydroponic, dan umur panen

\section{PENDAHULUAN}

Salah satu faktor utama dalam usaha bidang peternakan yang mempengaruhi performa produktivitas ternak ruminansia ialah pakan. Hijauan merupakan sumber pakan utama bagi ternak ruminansia, sehingga untuk meningkatkan produksi ternak ruminansia 
harus diikuti dengan peningkatan ketersediaan hijauan yang cukup baik dalam kuantitas maupun kualitas. Permasalahan utama dalam penyediaan hijauan pakan konvensional yang berasal dari budidaya dan alam sangat terbatas, dikarenakan terjadinya alih fungsi lahan pastura menjadi lahan pertanian, pemukiman, dan industry (Septian et al., 2018). Perubahan iklim juga dapat mempengaruhi kualitas dan kuantitas produksi hijauan pakan.

Berdasarkan permasalahan tersebut, diperlukan solusi alternatif sehingga dapat mengatasi permasalahan ketersediaan hijauan pakan di lahan terbatas dan ketidakpastian iklim. Salah satu alternatif solusinya adalah denganmenggunakansistemtanamhidroponik. Hidroponik merupakan teknik budidaya hijauan pakan yang cocok diaplikasikan untuk mengatasi kendala ketergantungan iklim dan ketersediaan lahan (Chrisdiana, 2018). Hijauan pakan yang dibudidayakan secara hidroponik sering disebut dengan green fodder hydroponic. Menurut Wahyono et al. (2018), budidaya hijauan pakan secara hidroponik dilakukan dalam periode yang singkat, hanya menggunakan media cair dan dilakukan di lingkungan yang terkontrol.

Beberapa penelitian sebelumnya telah menjelaskan berbagai kelebihan green fodder hydroponic. Kumalasari et al. (2017) mengemukakan bahwa hijauan pakan hasil budidaya hidroponik mengandung protein kasar (PK) yang tinggi serta menurut Wahyono et al. (2019) mengandung bahan kering yang tinggi daripada hijauan yang ditanaman secara konvensional. Hal ini juga diperkuat oleh Wahyono et al. (2018) yang menjelaskan bahwa sorghum green fodder hydroponic mengandung nutrien yang tinggi dan rendah cemaran bahan berbahaya bagi ternak. Tanaman serealia (jagung, gandum, barley dan sorgum) merupakan jenis tanaman yang banyak dibudidayakan secara hidroponik sebagai pakan ternak. Sorgum merupakan tanaman yang potensial dikembangkan sebagai green fodder hydroponic karena berkembang baik di lingkungan tropis dan efisien dalam menghasilkan produk fotosintesis (Chrisdiana, 2018).

Sorghum green fodder hydroponic dapat dipanen pada umur 7-13 hari. Umur panen mempengaruhi produktivitas dan kandungan nutrien sorghum green fodder hydroponic. Wahyono et al. (2019) menyatakan bahwa hasil budidaya hidroponik dipengaruhi oleh umur pemanenan. Penelitian tentang pengaruh umur panen berbeda terhadap kandungan dan produksi bahan kering (BK) dan protein kasar (PK) sorgum yang dibudidayakan secara hidroponik belum banyak dilakukan di Indonesia. Oleh sebab itu, perlu dilakukan penelitian tentang pengaruh umur panen yang berbeda terhadap kandungan dan produksi bahan kering serta protein kasar sorghum green fodder hydroponic.

\section{MATERI DAN METODE}

Bahan yang digunakan dalam penelitian ini yaitu biji sorgum varietas numbu sebanyak $0,38 \mathrm{~g} / \mathrm{cm}^{2}$ (Wahyono et al., 2019) atau sebanyak $106 \mathrm{~g} /$ nampan dengan total 18 nampan serta dibutuhkan air untuk merendam dan menyiram. Adapun peralatan yang digunakan dalam penelitian ini diantaranya nampan, drum, gelas ukur, sprayer, kain penutup, termohigrometer, termometer, timbangan digital, dan alat tulis, serta seperangkat analisis kandungan BK (AOAC, 1990) dan PK (AOAC, 1980) sorghum green fodder hydroponic.

Penelitian dilakukan secara eksperimental menggunakan rancangan acak lengkap, data yang terkumpul dianalisis dengan Uji Duncan menggunakan Aplikasi IBMSPSS23. Hubungan antara umur panen dengan kandungan dan produksi BK dan PK digunakan analisis regresi (Steel dan Torrie, 1993).

\section{HASIL DAN PEMBAHASAN}

Hasil uji kandungan dan perhitungan produksi BK dan PK Sorghum Green Fodder Hydroponic menunjukkan bahwa adanya perubahan pada setiap umur panennya. Hal ini menunjukkan bahwa adanya pengaruh umur panen terhadap kandungan dan produksi BK dan PK Sorghum Green Fodder Hydroponic. Hasil uji kandungan dan perhitungan produksi BK dan PK disajikan pada Tabel 1.

Data di atas menunjukkan bahwa produksi bahan segar, kandungan BK, produksi BK, dan kandungan PK menunjukkan perbedaan yang nyata $(p<0,05)$. Sedangkan pada produksi PK menunjukkan perbedaan yang tidak nyata $(p>0,05)$. Semakin lama masa panen, produksi bahan segar sorghum green fodder hydroponic menurun. Hal ini dapat dikarenakan tanaman kekurangan nutrien untuk pertumbuhan. Sebagaimana dikemukakan oleh Andriani dan Isnaini (2013), bahwa sorgum yang ditanam dengan media tanah berumur antara 3-10 hari 
Tabel 1. Pengaruh Umur Panen Berbeda terhadap Kandungan dan Produksi BK dan PK Sorghum Green Fodder Hydroponic

\begin{tabular}{|c|c|c|c|}
\hline \multirow{2}{*}{ Parameter } & \multicolumn{3}{|c|}{ Perlakuan } \\
\hline & K1 & $\mathrm{K} 2$ & K3 \\
\hline Produksi Bahan Segar (g) & $239,47 \pm 34,91^{\mathrm{a}}$ & $206,97 \pm 12,33^{b}$ & $168,02 \mathrm{~g} \pm 12,55 \mathrm{c}$ \\
\hline Kandungan BK (\%) & $25,93 \pm 2,05 a$ & $28,18 \pm 1,96 b$ & $31,19 \pm 0,64 \mathrm{c}$ \\
\hline Produksi BK (g) & $61,80 \pm 2,48 a$ & $58,16 \pm 2,47 b$ & $52,40 \pm 3,90 b$ \\
\hline Kandungan PK (\%) & $20,33 \pm 0,77 a$ & $22,45 \pm 0,67 b$ & $24,23 \pm 0,34 c$ \\
\hline Produksi PK (g) & $12,56 \pm 0,62 a$ & $13,05 \pm 0,34 a$ & $12,69 \pm 0,94 a$ \\
\hline
\end{tabular}

setelah tanam, pertumbuhannya bergantung pada nutrien dan cadangan pangan dari benih. Rahmawati (2021) juga menyatakan bahwa fase pertumbuhan sorgum dikelompokkan pada tiga tahap yaitu fase vegetatif, fase generatif dan pembentukan biji. Sorghum green fodder hydroponic ditanam hanya pada fase vegetatif. Pada fase vegetatif ada tiga tahap, namun sorghum green fodder hydroponic hanya ditanam sampai pada tahap 1, yakni antara 0-19 hari. Tahap 0 adalah saat kecambah muncul di atas permukaan media. Pada kondisi yang optimum, tahap ini terjadi antara 3-10 hari setelah tanam (HST). Munculnya kecambah dipengaruhi oleh suhu, kelembaban, kedalaman posisi benih, dan vigor benih. Pada suhu tanah $20^{\circ} \mathrm{C}$ atau lebih, tunas pucuk (coleoptile) muncul di atas tanah setelah 3-4 HST, dan akan lebih lama jika suhu semakin rendah. Sedangkan akar skunder akan mulai berkembang 3-7 HSB. Selama tahap ini, pertumbuhan bergantung pada nutrisi dan cadangan makanandari benih. Selanjutnya tahap 1, yaitu saat pelepah daun ke-3 terlihat. Daun dihitung setelah pelepah daun mulai terlihat atau tidak lagi tertutup oleh pelepah daun sebelumnya, namun titik tumbuh masih berada di tanah. Laju pertumbuhan relative lambat. Tahap ini berlangsung pada umur sekitar 10-19 HSB. Menurut Cuddeford (1989), pati pada tanaman serealia merupakan bahan baku yang mendukung pertumbuhan tanaman. Pemberian air selama proses perendaman akan mengaktifkan enzim dalam biji yang menghidrolisis pati menjadi gula yang tersedia untuk pertumbuhan embrio. Dalam kondisi kelembapan, oksigen dan kehangatan yang optimal, gula akan digunakan untuk sintesis dinding sel dan menyediakan energi untuk pertumbuhan.

Penelitian ini sesuai dengan penelitian Wahyono et al. (2018) bahwa semakin lama masa panen maka kandungan BK akan semakin meningkat dengan kandungan BK $27,55 \%$ sampai dengan $29,74 \%$, meningkatnya kandungan BK disebabkan karena meningkatnya konversi nutrisi yang diperoleh dari air dan simpanan dalam biji selama proses pemeliharaan. Kenaikan persentase bahan kering pada hijauan juga disebabkan oleh menurunnya persentase kadar air tanaman yang sudah tua. Tanaman yang masih muda cenderung memiliki kandungan air yang lebih tinggi, sehingga persentase bahan keringnya menjadi rendah. Semakin tua umur tanaman biasanya ada peningkatan kandungan serat kasar dan protein kasar yang dapat mempengaruhi peningkatan kandungan BK. Hal ini disebabkan oleh umur tanaman yang semakin tua mempunyai komponen dinding sel yang tinggi. Sehubungan dengan perkembangan kedewasaan (umur tanaman) hijauan, maka akan terjadi pula peningkatan konsentrasi seratnya (Savitri et al., 2012). Hubungan lama umur panen dengan kandungan BK sorghum green fodder hydroponic dapat dilihat pada Namun, hal ini kontradiktif dengan penelitian Fazaeli et al. (2012) yang menunjukkan bahwa semakin lama umur panen maka kandungan BK akan semakin turun dengan kandungan 13,3\% sampai dengan $19,27 \%$. Perbedaan hasil penelitian ini dapat disebabkan karena perbedaan komoditas tanaman, nutrien yang diberikan, umur panen dan kondisi lingkungan. Penelitian Fazaeli et al. (2012) menggunakan biji barley yang dipanen pada hari ke 6, 7, dan 8. Sedangkan pada penelitian ini menggunakan biji sorgum yang dipanen pada hari ke 7, 10, dan 13.

Semakin lama umur panen sorghum green fodder hydroponic maka produksi BK akan semakin menurun meskipun kandungan BK naik. Hal ini disebabkan karena produksi bahan segar sorghum green fodder hydroponic yang 
semakin menurun saat umur panen semakin lama, sehingga berdampak pada produksi BK. Selain itu, menurut Alberto et al. (2017) pada saat pemanenan lebih awal biomassa hijauan produksi bahan kering akan lebih tinggi karena pada kepadatan tanaman masih terdapat benih utuh yang tidak tumbuh baik. Selanjutnya didukung oleh pendapat Zabed et al. (2016) saat pemanenan hari ke-7 biomassa hijauan produksi bahan keringnya akan lebih tinggi karena pada kepadatan tanaman masih terdapat benih utuh yang tidak tumbuh baik sehingga penyerapan air dan mineral dari tanaman akan semakin berkurang. Kamlasi et al. (2012) menjelaskan bahwa banyaknya produksi BK diiringi dengan produksi bahan segar. Menurut Rusdy (2012) menurunnya produksi BK disebabkan karena rendahnya kemampuan fotosintesis akibat rendahnya luas daun yang tersisa dan rendahnya kandungan karbohidrat cadangan pada pangkal batang dan akar.

Kandungan PK tertinggi didapat pada hari panen ke-13. Semakin lama umur panen, kandungan PK semakin tinggi. Hal ini sesuai dengan hasil penelitian Chrisdiana (2018); Wahyono et al. (2018); Akbag et al. (2014); dan Fazaeli et al. (2012) bahwa semakin lama umur panen akan meningkatkan kandungan PK pada hidroponik fodder. Pada penelitian Chrisdiana (2018) kandungan PK sorghum green fodder hydroponic berkisar antara $17,27 \%$ sampai dengan 26,68 dalam masa panen antara 8-16 hari. Peningkatan tersebut disebabkan karena adanyapenurunanpersentasefraksikarbohidrat yang digunakan selama pertumbuhan tanaman sehingga akan meningkatkan persentase PK. Proses pembentukan karbohidrat melalui proses fotosintesis. Menurut Wiraatmaja (2017), fotosisntesis adalah suatu proses biokimia pembentukan zat makanan seperti karbohidrat yang dilakukan oleh tumbuhan, terutama tumbuhan yang mengandung zat hijau daun atau klorofil. Organisme ini berfotosintesis dengan menggunakan zat hara, $\mathrm{CO}_{2^{\prime}}$ dan air serta bantuan energi cahaya matahari. Proses fotosintesis dimulai dengan energi cahaya diserap oleh protein berklorofil yang disebut pusat reaksi fotosintesis. Pada tumbuhan, protein ini tersimpan di dalam organel yang disebut kloroplas. Akbag et al. (2014) juga melaporkan bahwa selama perkecambahan dan pertumbuhan, tanaman menggunakan cadangan karbohidrat yang berasimilasi dengan aktivitas metabolismenya sehingga hal ini akan meningkatkan fraksi PK.Semakin lama umur panen kandungan PK semakin meningkat namun produksi BK semakin menurun, sehingga laju pertumbuhannya beririsan dan berdampak pada produksi PK yang tidak signifikan. Hal ini sesuai dengan penelitian Chrisdiana (2018) yang menjelaskan bahwa produksi protein kasar sorghum green fodder hydroponic tidak berbeda nyata pada waktu panen karena peningkatan persentase protein kasar sebanding dengan penurunan persentase produksi bahan kering, sehingga kandungan protein kasar sebenarnya tidak terjadi dalam kilogram.

\section{KESIMPULAN DAN SARAN}

\section{Kesimpulan}

Semakin lama umur panen sorghum green fodder hydroponic, produksi bahan segar dan produksi bahan kering semakin menurun, namun kandungan bahan kering dan protein kasar terus meningkat. Tidak terjadi perbedaan yang nyata pada produksi protein kasar karena peningkatan persentase protein kasar sebanding dengan penurunan produksi bahan kering, sehingga kandungan protein kasar sebenarnya tidak terjadi dalam kilogram.

\section{Saran}

Dapat dilakukan penelitian selanjutnya pada umur panen yang lebih lama karena kandungan dan produksi BK dan PK kemungkinan akan memiliki titik puncak tertentu dan akan mengalami penurunan.

\section{DAFTAR PUSTAKA}

Akbag, H. I., O. S. Turkmen, H. Baytekin \& I. Y. Yurtman. 2014. Effects of harvesting time on nutritional value of hydroponic barley production. Turkish J. Agric. and Natural Sci. Special Issue, 1(2): 1761-1765.

Alberto C. M., A. Ibarz, dan P. E. D. Augusto. 2017. Ultrasound technology enhances the hydration of corn kernels without affecting their starch properties. Journal of Food Engineering, 197: 34-43.

Andriani, A., dan M. Isnaini. 2013. Morfologidan Fase Pertumbuhan Sorgum Dalam Sorgum Inovasi Teknologi Dan Pengembangan, $X$. ed. IAARD PRESS. Jakarta. 
AOAC. 1980. Official Methods of Analysis. Association of Official AnalyticalChemists, INC. Arlington, Virginia, USA.

AOAC. 1990. Official Methods of Analysis 15th Edition. Association of Official Analytical Chemists, INC. Arlington, Virginia, USA.

Chrisdiana, R. 2018. Quality and quantity of sorghum hydroponic fodder from different varieties and harvest time. In IOP Conference Series: Earth and Environmental Science. 119, p. 012014

Dung D. D., I. R. Goodwin, dan J.V. Nolan. 2010. Nutrient Content and in sacco Digestibility of Barley Grain and Sprouted Barley. J. Anim. Vet. Advances, 9 (19): 2485.

Fazaeli, H., H.A. Golmohammadi, S.N. Tabatabayee, \& M. Asghari-Tabrizi. 2012. Productivity and nutritive value of barley green fodder yield in hydroponic system. World Appl. Sci. J, 16(4):531-539.

Kamlasi, Y., L. Marthen, Mullik, dan T. O. D. Dato.2012. Pola produksi dan nutrisi Rumput Kume (Sorghum plumosum var. Timorense) pada lingkungan alamiahnya. Jurnal Ilmu-Ilmu Peternakan, 24 (2): 3140.

Kumalasari, N. R., A.T. Permana, R. Silvia dan A. Martina. 2017. In The 7th International Seminar on Tropical Animal Production. 8 Mei. 1-7.

Rahmawati. 2021. Fase Pertumbuhan Tanaman Sorgum Menurut Balai Penelitian Tanaman Seralia. http://cybex.pertanian. go.id/artikel/95199/fase-pertumbuhantanaman-sorgum/. 09 Juni 2021 (05.38 WIB).
Septian, M.H., I. Hernaman., R. Wiradimadja., F.T. Santoso. 2018. Performance and Diet Digestibility of Male Garut Lamb Fed Ipomea reptans Seed. Buletin Peternakan 42 (4): 278-282, November 2018.

Savitri, M. V., Herni Sudarwati dan Hermanto. 2012. Pengaruh umur pemotongan terhadap produktivitas gamal (Gliricidia sepium). Fakultas Peternakan Universitas Brawijaya. Malang.

Steel, R. G. D and J. H. Torrie. 1993. Prinsip dan Prosedur Statistika. PT. Gramedia Pustaka Utama, Jakarta.

Wahyono, T., H. Khotimah, W. Kurniawan, D. Ansori, dan A. Muawanah. 2019. Karakteristik tanaman sorghum green fodder (SGF) hasil penanaman secara hidroponik yang dipanen pada umur yang berbeda. Jurnal Ilmu dan Teknologi Peternakan Tropis, 6(2): 166-174.

Wahyono, T., S.N.W. Hardani, dan I. Sugoro. 2018. Low irradiation dose for sorghum seed sterilization: hydroponic fodder system and in vitro study. Buletin Peternakan, 42(3): 215-221.

Wiraatmaja, I. W. 2017. Metobolisme pada Tumbuhan. Bahan Ajar Program Studi Agroteknolgi Universitas Udayana, Denpasar.

Zabed, H., N.A. Boyce, N. J. Sahu, and F. Golam, 2017. Evaluation of the quality of dried distiller's grains with solubles for normal and high sugary corn genotypes during dry-grind ethanol production. Journal of Cleaner Production, 142 (4): 4282-4293. 